\title{
ANALISIS PERANAN PAJAK DALAM PERTUMBUHAN PEREKONOMIAN DI INDONESIA
}

\author{
WA TIMA MEGA \\ Mahasiswa Program Studi Ekonomi Syariah STAI Al-Azhar Gowa \\ watimamega@gmail.com
}

\begin{abstract}
Abstrak
Pajak merupakan kontribusi wajib negara yang terutang oleh orang pribadi atau badan yang bersifat memaksa berdasarkan Undang-Undang,dengan tidak mendapatkan imbalan secara langsung dan digunakanuntuk keperluan negara bagi sebesar-besarnya kemakmuran rakyat.Hasil dari penelitian yang telah dilakukan,ditemukannya berbaai peranan pajak dalam pertumbuhan perekonomian di Indonesia.Pajak memiliki dampak pada pertumbuhan ekonomi suatu negara layaknya pada para pedagang bermata dua.Disisi lain penerimaan pajak yang tinggi juga mampu memacu sebuah negara untuk meningkatkan belanja-belanja pemerintah yang dapat memacu perekonomian hingga berujung pada terciptanya kenaikan tingkat pertumbuhan ekonomi.Sebagai warga negara Indonesia itu wajib membayar pajak. Menurut teori neo klasik, suatu ekonomi itu bergantung pada pertambahanya penyediaan factor-faktor produksi dan tingkat kemajuan teknologi.
\end{abstract}

Kata kunci : pajak,Undang-Undang,pertumbuhan ekonomi.

\section{A.Pendahuluan}

Pada tahun 1966 hingga sampai saat ini,perekonomian yang ada di Indonesia telah berkembang begitu pesat.Di awali dengan tiga tahun tahap stabilitasi dan rehabilitasi pada tahun 1966- 1968,memasuki tanggal 1 April 1969 dimulailah tahap- tahap pembangunan bencana lima tahun atau pelita.Setelah melewati masa tiga pelita (1969-1984),saat ini tahap pembangunan telah memasuki tahun pertama Pelita IV.Selama periode 1969-1983 data-data yang ada menunjukkan bahwa produk domestic bruto (BDP) dengan harga konstan tahun 1973 telah meningkat sebanyak 3,24 kali. ${ }^{1}$

Dalam upaya untuk mencapai target pertumbuhan ekonomi yang lebih baik, APBN (Anggaran Pendapatan dan Belanja Negara) selalu berpedoman kepada prinsip anggaran yang berimbang dan dinamis.Dengan adanya peningkatan dalam penerimaan zakat,maka itu akan berpengaruh terhadap pertumbuhan ekonomi di Indonesia.Karena penerimaan tersebut dapat

\footnotetext{
${ }^{1}$ Bambang Triyoso, "Analisa Statistik Atas Besarnya Parameter Ekonomi Makro: Sisi Lain Dari Pengamatan Teoritis Perkembangan Perekonomian Indonesia 1968 - 1983," Economics and Finance in Indonesia 32, no. 3 (1984): 317-40.
} 
digunakan sebagai penyelengaraan negara. ${ }^{2}$ Pajak mempunyai peranan yang sangat penting dalam kehidupan bernegara,khususnya di dalam pelaksanaan pembangunan karena pajak merupakan sumber pendapatan Negara untuk membiayai semua pengeluaran termasuk pengeluaran pertumbuhan ekonomi.Pemerintah juga dapat mengatur pertumbuhan perekonomian melalui kebijaksanaan pajak.

Tetapi dalam masa sekarang,dengan adanya penutupan berbagai perusahaan di Indonesia ditambah dengan banyaknya kasus-kasus PHK yang terjadi,bagaimana masyarakat Indonesia sendiribdalam membayar pajaknya?Tidak semudah itu meningkatkan perekonomian nasional di era sekarang,meskipun masa sekrang bisa dikatakan pajak merupakan pendapatan yang paling bisa dimanfaatkan.Direktur Jenderal Pajak Keuangan Suryono Utomo mrnuturkan,pelaporan Surat Pemberitahuan Pajak (SPT) Tahunan di 2020 sudah mecapai 13 juta wajib pajak. Angka tu meningkat tipis di banding realisasi pelaporan SPT Tahunan 2019 sebanyak 12,8 juta laporan.

Berdasarkan pernyataan tersebut membuktikan bahwa kondisi di Indonesia pada masa covid 19 masih normal-normal saja.Bahkan ada sedikit peningkatan berdasarkan Direktorat Jenderal pajak.Namun ada juga yang mengatakan bahwa pada masa covid 19 sekarang ini,paajak sedikit mengalami penurunan akibat dari penurunan perekonomian dalam negeri (Indonesia) juga.

Sebuah nilai tukar juga berpengaruh terhadap besaran pertumbuhan ekonomi.Dalam perekonomian terbuka,tingkat pertumbuhan juga akan dipengaruhi oleh nilai tukar.Pengaruh nilai tukar terhadap tingkat pertumbuhan dapat dilihat baik melalui jalur anggregate supply (AS),yakni melalui pembentukan capital,maupun melalaui aggregate demand (AD),yakni melalui pemebentukan capital,maupun melalui aggregate demand (AD) ,yakni melalui transaksi perdagangan internasional dan investasi.Adapun penenlitian ini bertujuan untuk melihat pengaruh ekspor,penerimaan pajak dan nilain tukar secara persial dan simultan terhadap pertumbuhan ekonomi di Indonesia. ${ }^{3}$ Oleh karena itu,pajak di instrumentasikan sebagai pemulihan ekonomi di Indonesia. Dalam hal ini pajak memiliki dua peran,yaitub sebagai instrument untuk stabilitas san pemulihan ekonomi serta memenuhi target penerima pajak.

Adapun penelitian ini bertujuan untuk mengetahui analisis suatu peranan pajak dalam perekonimian terhadap pertumbuhan perekonomian di Indonesia.

\section{B.Pembahasan}

\section{Pajak dalam Perekonomian Nasional}

Untuk mendukung upaya penerimaan dalam negeri dari sektor pajak maka ditempuh berbagai kebijasanaan terutama yang dikenal dengan reformasi di bidang perpajakan dengan diundangkannya berbagai UU yang berkaitan dengan bidang perpajakan ini.Fundamental reformasi yang ada saat ini,khusus terkait policy,ada dua gambaran besar yaitu bagaimana mengumpulkan penerimaan.Berbagai upaya dilakukan agar adanya upaya untuk tidak terlalu bergantung kepada sektor migras.Dengan begitu dilakukannya intensifikasi ekstensifikasi

\footnotetext{
2 Hudiyanto Hudiyanto, “Peranan Pajak Dalam Perekonomian Indonesia," Unisia 13, no. 15 (1992): 83-92, https://doi.org/10.20885/unisia.vol13.iss15.art8.

${ }^{3}$ Rinaldi Syahputra, “Analisis Faktor-Faktor Yang Mempengaruhi Pertumbuhan Ekonomi Di Indonesia” 1, no. 2 (2017): 183-91.
} 
penarikan pajak,sehingga peran pajak mampu meningkat dalam penerimaanya di dalam negeri sebagaimana di tunjukkan dalam table 1.

Tabel 1 Penerimaan Dalam Negeri,

Penerimaan dari Migas, Dan Penerimaan di Luar Migas, 1981 - 1990

\begin{tabular}{|l|c|c|c|c|c|c|c|c|c|c|}
\hline & $\begin{array}{c}1981 / \\
82\end{array}$ & $\begin{array}{c}1982 / \\
83\end{array}$ & $\begin{array}{c}1983 / \\
84\end{array}$ & $\begin{array}{c}1984 / \\
85\end{array}$ & $\begin{array}{c}1985 / \\
86\end{array}$ & $\begin{array}{c}1986 / \\
87\end{array}$ & $\begin{array}{c}1987 / \\
88\end{array}$ & $\begin{array}{c}1990 / \\
91\end{array}$ & $\begin{array}{c}\left.1991 \%^{*}\right) \\
92\end{array}$ & $\begin{array}{c}\left.1992 /^{*}\right) \\
93\end{array}$ \\
\hline $\begin{array}{l}\text { Penerimaan Dlm.Neg. } \\
\text { Penerimaan dari } \\
\text { pajak non migas } \\
\begin{array}{l}\text { Persentase pajak } \\
\text { dari Pen. Total }\end{array}\end{array}$ & 12.213 & 12.418 & 14.433 & 15.905 & 18.678 & 19.253 & 17.833 & 31.583 & 40.184 & \\
\hline
\end{tabular}

*) RAPBN

Sumber : Bank Indonesia, Laporan Tahunan, berbagai tahun

Dari table 1 nampak bahwa peranan sektor pajak dalam penerimaan dalam negeri relative rendahbpada tahun 1981 yaitu hanya 29 persen dari total penerimaan dalam negeri. Tetapi perannya mulai mengalami kenaikan yang cukup berarti setelah tahun 1982 yaitu mencapai 34 persen dari total penenerimaan dalam negeri dan mengalami penjolakan pada tahun 1986 dan tahun- tahun berikutnya yang mencapai diatas angka 45 persen. ${ }^{4}$

teori neo klasik,suatu ekonomi itu bergantung pada pertambahanya penyediaan faktorfaktor produksi (penduduk,tenaga kerja,dan akumulasi modal)dan tingkat kemajuan teknologi.Dengan adanya pembentukan modal dapat menghasilkan kemajuan sehinngga dapat tercapainya sebuah ekonomi produksi skala luas dan meningkatkankan spesialisasi. Adapun yang menjadi persoalan hingga saat ini,yaitu terjadinya paradoks dalam pembangunan ekonomi Indonesia,di mana kenyataannya yang terjadi di tengah-tengah masyarakat,berdasarkan data BPS terlihat meskipun laju pertumbuhan ekonomi pasca krisis 1997 cenderung meningkat, namun angka pengangguran juga meningkat.Pada tahun 2005 pertumbuhanekonomi Indonesia cukup signifikan dari 5,03 persen tahun 2003 meningkat menjadi 5,69 persen pada tahun 2005.Namun,kenaikan pertumbuhan ekonomi ini ternyata belum mampu menciptakan lapangan kerja dan menyerap tambahan Angkatan kerja,akibatnya jumlah penangguran justru meningkat dari 10,25 juta atau sekitar 9,56 persen pada tahun 2003 menjadi sebesar 10,85 juta atau sekita 11,24 persen total Angkatan kerja dari tahun sebelumnya.Namun di sisi lain ada faktor yang menyebabkan kenaikan besar suatu ekonomi karna adanya suatu investasi yang baik dalam bentuk Penanaman Modal Dalam Negeri (PMDN ) maupun Penanaman Modal Asing (PMA) yang memainkan peranan penting dalam menentukan tingkat pertumbuhan ekonomi dan upaya pengentasan kemiskinan di Indonesia. ${ }^{5}$

Pajak memiliki dampak pada pertumbuhan ekonomi suatu negara layaknya pedagang bermata dua.Disisi lain penerimaan pajak yang tinggi dapat memacu sebuah negara untuk meningkatkan belanja-belanja pemerintah yang dapat memacu perekonomian hingga berujung

\footnotetext{
${ }^{4}$ Hudiyanto, "Peranan Pajak Dalam Perekonomian Indonesia."

${ }^{5}$ Arius Jonaidi, "Bahan Mendeley Analisis Pertumbuhan Ekonomi Dan Kemiskinan," Kajian Ekonomi 1, no. April (2012): 140-64.
} 
pada terciptanya kenaikan tingkat pertumbuhan ekonomi. ${ }^{6}$ Adanya penanaman Modal juga penerimaan pajak ini menjadikan sebagai sumber pendapatan negara yang dominan,oleh karena itu di tingkatkan penerimaanya.Berdasarkan alur pikir teori keuangan daerah,penerimaan pajak umumnya digunakan untuk membiayai jasa pelayanan yang bersifat semi public (semi public goods) dimana komponen manfaat individunya relatif besar. Komponen utama dalam pendapatan fiscal adalah sektor perpajakan.Diberbagai negara didunia ini sektor perpajakan mampu menyumbang lebih dari $50 \%$ pendapatan fiscal.Hal ini menjadikan sektor pajak merupakan sektor penting dan signifikan yang harus dikelola secara optima(Camelia : 2005).

Karena pajak berkaitan dengan disposable income maka ia berkaitan dengan multiplier effect atau angka pengganda perekonomian. Termasuk dalam hal ini adalah pengaruhnya nanti terhadap iklim investasi dan anggaran berimbang yang di anut oleh pemerintah.

\section{Kebijakan di Bidang Perpajakan}

Dalam literatur ekonomi pajak merupakan komponen yang amat penting dalam menjalankan roda perekonomian (Boadway,1986).Ia merupakan alat bagi pemerintah untuk melakukan kebijakan fiskalnya,yaitu untuk mempengaruhi aktifitas ekonomi dalam masyarakat.Apabila pemerintah merasa bahwa perekonomian tumbuh terlalu cepat maka ia bisa mengendalikannya dengan pengetatan penarikan pajak (kebijaksanaan kontraksi).Fungsi pemerintah pada masa sekarang meliputi pertama,fungsi untuk mengalokasikan output dan sumberdaya; kedua,fungsi pemerintah untuk melakukan distribusi kemakmuran bangsa;ketiga fungsi untuk melakukan stabilitas perekonomian. ${ }^{7}$ Maka dari itu pemerintah sangat berperan penting dalam segala hal yang terkait mengenai urusan perpajakan dan sebagai kemakmuran untuk masyarakat mengenai perpajakan tersebut sehingga bisa membuat stabil perekonomian.

Dalam kaitan ini,meskipun pemerintah "dibenarkan" untuk menarik pajak dari masyaraknya untuk membiayai pembangunan,tetapi dibandingkan dengan banyak negara yang lain,pemerintah Indonesia terkesan "tidak sungguh-sungguh" dalam menggali sumber pajak ini (Uppal,1986) paling tidak sampai awal delapan puluhan.Hal itu terlihat dari Tabel 2 yang membandingkan perimaan pajak oleh beberapa negara dihitung penerimaan pajak perkapita.

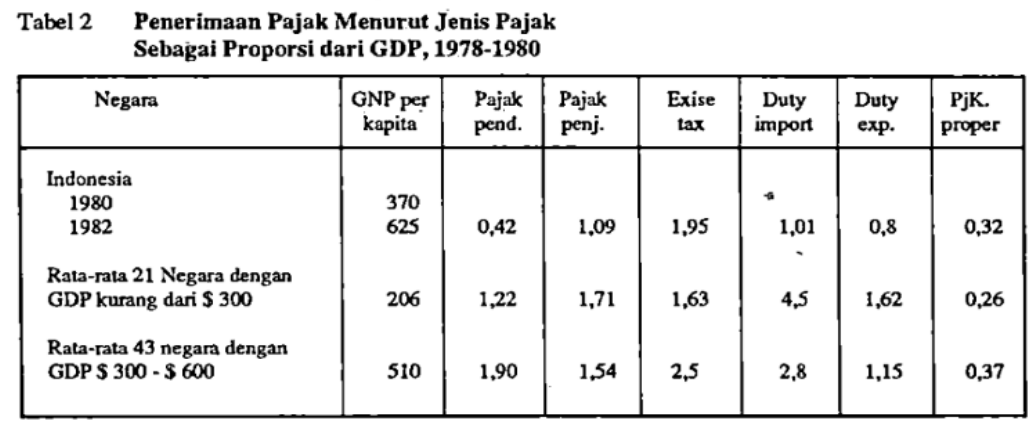

Sumber : (Uppal, 1986)

Dari table 2 nampak bahwa dibandingkan dengan negara-negara dengan GDP yang lebih rendah hasil penarikan pajak dari masyarakat Indonesia masih tertinggal.Untuk pajak kekayaan yang merupakan fungsi dari pendapatan nasional misalnya,Indonesia hanya

\footnotetext{
${ }^{6}$ Nurhidayati Islamiah, “Analisis Pengaruh Belanja Pembangunan/Modal Dan Tingkat Inflasi Terhadap Pertumbuhan Ekonomi Dan Penerimaan Pajak Di Indonesia," Jurnal Economix 3, no. 1 (2015): 46-57.

${ }^{7}$ Hudiyanto, "Peranan Pajak Dalam Perekonomian Indonesia."
} 
menunjukkan angka 0,42\% semntara negara dengan pendapatan yang leboh rendah mencapai lebih dua kali lipatnya yaitu 1,22 dan dibandingkan dengan negara yang sederajat tingkat GDPnya, hanya seperempatnya,yaitu 1,90\%.Kesimpulannya adalaah bahwa Indonesia tidak banyak menggunakan pajak sebagai sumber penerimaannya.

\section{Pajak Penghasilan}

Undang-Undang Pajak Penghasilan 1984 untuk menggantikan 1925,UU PBDR tahun 1970 dan UU No.8 tahun 1967 tentang MPO dan MPS pada dasarnya merupakan upaya untuk meningkatkan penerimaan dalam negeri dari sektor pajak.Undang-Undang yang mulai diberlakukan pada 1 Januari itu pada dasarnya menyederhanakan dan menurunkantarif pajak rata-rata.Tujuan dari kebijaksanaan itu adalah untuk mendorong partisipasi masyarakat dalam membayar pajak kepada negara.

Pajak untuk menghitung, memperhitungkan, membayar, dan melaporkan sendiri besarnya pajak yang harus dibayar. Ciri-ciri dari sistem ini adalah :

a.untuk menentukan besarnya pajak terutang ada pada Wajib Pajak sendiri,

b. Wajib Pajak aktif, mulai dari menghitung, menyetor dan melaporkan sendiri pajak yang terutang,

c. Fiskus tidak ikut campur dan hanya mengawas ${ }^{8}$

\section{Komitmen Perusahaan Menjadi Muzakki}

Mengenai proses regulasi pengelolaan zakat (Wahid,2018) hingga zakat mengurangi pembayaran pajak (dalam hal ini pajak penghasilan),hal ini sudah diatur sejak adanya UU No.38 Tahun 1999 tentang Pengelolaan Zakat,dan kemudian lebih dipertegas oleh UU Zakat yang terbaru yang menggantikan.

Undang-undang 38/1999 yaitu UU No.23 Tahun 2011 tentang Pengelolaan Zakat.Latar belakang dari pengurangan ini dijelaskan dalam penjelasan Pasal 14 ayat (3) UU 38/1999 bahwa pengurangan zakat dari laba/pendapatan sisa kena pajak adalah dimaksudkan agar wajib pajak tidak terkena beban ganda,yakni kewajiban membayar zakat dan pajak.Ketentuan ini masih diatur dalam UU yang terbaru yakni dalam Pasal 22 UU 23/2011 "Zakat yang dibayarkan oleh muzaki kepada BAZNAS atau LAZ dikurangkan dari penghasilan kena pajak"(Wahid,2018).

Pemegang saham (Pertiwi \& Laily, 2018)merupakan bagian dari pemilik perusahaan yang mewakilkan operasionalnya kepada pihak manajemen untuk menjalankan operasional perusahaan dimana keutungan dan kerugian perusahaan ditanggung bersama oleh pemegang saham. Keuntungan dan kerugian perusahaan dapat diketahui pada waktu Rapat Umum Pemegang Saham (RUPS) dan pada saat itulah zakat di wajibkan. Namun para ulama berbeda tentang kewajiban pengeluaran zakatnya. ${ }^{9}$

\footnotetext{
${ }^{8}$ Marisa Herryanto and Agus Arianto Toly, "Pengaruh Kesadaran Wajib Pajak, Kegiatan Sosialisasi Perpajakan, Dan Pemeriksaan Pajak Terhadap Penerimaan Pajak.," Accounting and Tax Review 1, no. 1 (2013): 125-35.

${ }^{9}$ Ruslang Ruslang, Samsul Samsul, and Mujetaba Mustafa, "Komitmen Perusahaan Menjadi Muzakki," Al-Azhar Journal of Islamic Economics 2, no. 1 (2020): 25-35, https://doi.org/10.37146/ajie.v2i1.26.
} 


\section{Kesimpulan}

Dari urian di atas bisa di simpulkan ada dua hal yang berpengaruh dalam perekonomian.Pertama adanya kenyataan bahwa sebenarnys snggsrsn belanja Indonesia imtuk analisis multiplier adalah deficit,dengan menggunakan kriteria terketat.Kedua,terdapat usaha pemerintah yang cukup intensif untuk meningjatkan peran pajak sebagai tulang punggung perekonomian Indonesia.Upaya itu Nampak hasilnya dari peningkatan penerimaan dari pajak yang semakin tinggi sehingga persetase pajak penerimaan pemerintah semakin membesar.Dilakukannya juga intensifikasi-intensifikasi penarikan pajak,sehingga peran pajak mampu meningkat dalam penerimaanya di dalam negeri. Pasal 14 ayat (3) UU 38/1999 bahwa pengurangan zakat dari laba/pendapatan sisa kena pajak adalah dimaksudkan agar wajib pajak tidak terkena beban ganda,yakni kewajiban membayar zakat dan pajak. Adanya penanaman modal juga mampu memicu tingkat keinakan suatu pertumbuhan ekonomi dan upaya pengentasan kemiskinan di Indonesia.

\section{Daftar Pustaka}

Herryanto, Marisa, and Agus Arianto Toly. "Pengaruh Kesadaran Wajib Pajak, Kegiatan Sosialisasi Perpajakan, Dan Pemeriksaan Pajak Terhadap

Penerimaan Pajak." Accounting and Tax Review 1, no. 1 (2013): 125-35.

Hudiyanto, Hudiyanto. "Peranan Pajak Dalam Perekonomian Indonesia." Unisia 13, no. 15 (1992): 83-92. https://doi.org/10.20885/unisia.vol13.iss15.art8.

Islamiah, Nurhidayati. "Analisis Pengaruh Belanja Pembangunan/Modal Dan Tingkat Inflasi Terhadap Pertumbuhan Ekonomi Dan Penerimaan Pajak Di Indonesia." Jurnal Economix 3, no. 1 (2015): 46-57.

Jonaidi, Arius. "Bahan Mendeley Analisis Pertumbuhan Ekonomi Dan Kemiskinan." Kajian Ekonomi 1, no. April (2012): 140-64.

Ruslang, Ruslang, Samsul Samsul, and Mujetaba Mustafa. "Komitmen Perusahaan Menjadi Muzakki." Al-Azhar Journal of Islamic Economics 2, no. 1 (2020): 25-35. https://doi.org/10.37146/ajie.v2i1.26.

Syahputra, Rinaldi. “Analisis Faktor-Faktor Yang Mempengaruhi Pertumbuhan Ekonomi Di Indonesia” 1, no. 2 (2017): 183-91.

Triyoso, Bambang. "Analisa Statistik Atas Besarnya Parameter Ekonomi Makro: Sisi Lain Dari Pengamatan Teoritis Perkembangan Perekonomian Indonesia 1968 - 1983." Economics and Finance in Indonesia 32, no. 3 (1984): 317-40. 